\title{
TÜRKIYY'DE KATILIM BANKALARI VE MEVDUAT BANKALARININ FAİZ VE KAR ORANLARI İLE TAKIPTEKİ KREDİ ORANLARI ARASINDAKİ İLIŞKISİNIN BELİRLENMESİ
}

\author{
Harun KOLUKISA ${ }^{1}$
}

\begin{abstract}
Özet
Katılım bankaları mevduat bankalarına göre göreceli olarak daha yüksek kar/faiz oranlarından kredi kullandırmaktadır. Daha yüksek maliyetle kredi kullandıran katılım bankalarını mevduat bankalarına tercih eden müşterilerin daha düşük ödeme gücüne sahip sorunlu müşteri kitlesi olacağı ve bunun sonucu olarak da katılım bankalarının takipteki kredi oranlarının mevduat bankalarının takipteki kredi oranlarına göre daha yüksek olacağı öngörülmektedir. Bu çalışmada Ocak 2005 ve Eylül 2015 tarihleri arasında Türkiye'de faaliyet gösteren Katılım Bankalarının kredi kullandırımlarında uygulanan aylık kar oranları ve takipteki kredi oranları (NPL-non performing loan), Türkiye'de faaliyet gösteren Mevduat Bankaların kredi kullandırımlarında uygulanan aylık faiz oranları ve takipteki kredi oranları verileri kullanılmıştır. Katılım bankaları ve mevduat bankalarının kar ve faiz oranları ile takipteki kredi oranları arasındaki ilişki; korelasyon, VAR, Granger nedensellik ve etki-tepki analizleriyle incelenmiştir. Analizler neticesinde takipteki kredi oranlarının direkt olarak kar/faiz oranlarının bir sonucu olmadığı yönünde bulgular elde edilmiştir. Analiz sonuçlarına göre, öngörüldüğü gibi katılım bankalarının mevduat bankalarından daha yüksek kar/faiz oranından kredi kullandırması takipteki kredi oranlarını doğrudan etkilemediği belirlenmiştir.
\end{abstract}

Anahtar Kelimeler: Katılım Bankacılığı, Mevduat Bankacılığı, Faiz Oranları, Kar Oranları, NPL Rasyoları

\section{DETERMINING THE RELATIONSHIP BETWEEN PARTICIPATION BANK'S PROFIT RATES AND DEPOSIT BANK'S INTEREST RATES WITH NON-PERFORMING LOAN(NPL) RATIOS}

\begin{abstract}
Participation banks's credit profit rates are higher than depozit bank's credit interest rates. It is believed that, eventhough with higher financing costs, customers who choose participation banks over to deposit banks shall have a problematic profile that has lower payment power. Therefore, it is expected that paticiptaion bank's NPL ratios would be higher than depozit bank's NPL ratios.

Monthly profit rates applied for credits and non-performing loan(NPL) ratios of participation banks which are operating in Turkey, monthly interest rates applied for credits and NPL ratios of deposit banks which are operating in Turkey for the time between January 2005 and September 2015 are used. For determining the relationship between participation bank's profit rates and deposit bank's interest rates with NPL ratios; correlation, unit root test, VAR, Granger causality, and impulse-response analyses are applied. Due to analyese's results, NPL ratios are not direct result of profit/interest rates. In the light of analyses, it is determined that participation bank's higher profits rates for credit are not resulted to higher NPL ratio as it is foreseen.
\end{abstract}

Keywords : Participation Banks, Depozit Banks, Interest Rates, Profit Rates, NPL Ratios

${ }^{1}$ Doktora Öğrencisi, İstanbul Ticaret Üniversitesi Finans Enstitüsü, Finansal Ekonomi Bölümü, harunkolukisa@yahoo.com 


\section{GIRIŞ}

Bankaların temel ekonomik işlevleri mevduat sahiplerinden topladıkları fonları, finansman ihtiyacı olan ve kredi talep eden kişi ya da kurumlara ulaşmasında aracılık etmektir. Bankacılık sektörünün fon toplama ve finansman sağlama işlevleri sonucunda, ekonomiye kazandırılan fon hacmi ve bu fonlara talep artmaktadır. Bankaların önemli işlevlerinden biri de toplanan fonları ekonomik kalkınmaya katkı sağlayacak alan ve sektörlere yönelterek ülke ekonomisinin büyümesinde ve gelişmesinde olumlu etki yapmaktır. Sonuç olarak milli gelir ve istihdam artmasına katkı yaparlar (Arslan, Yapraklı, 2008).

Krediler Bankaların ağırlıklı faaliyet alanlarından biridir. Mevduat sahiplerinden topladığı fonları, kredi olarak fon talep eden gerçek kişilere(tüketicilere) ve tüzel kişilere(şirketlere) aktararak tekrardan ekonomiye kazandırır.

BDDK’nın hazırladığı Bankacılık sektörü raporlarına göre Türk bankacılık sektörünün aktif büyüklüğünün \%90.33'ünü mevduat bankaları, \%5.15'ini katılım bankaları ve \%4.5'ini kalkınma ve yatırım bankaları oluşturmaktadır. Katılım bankaları son 10 yıl dikkate alındığında ciddi bir büyüme gerçekleştirmiştir. Türk bankacılık sistemi son yıllarda büyümesiyle birlikte Mevduat bankalarının payında azalış gözlenmekte ve katılım bankalarının payında istikrarlı bir artış görülmektedir (BDDK, 2015).

Türkiye'de Katılım Bankacılığı olarak bilinen, dünyada İslami Bankacılık veya Faizsiz Bankacılık olarak isimlendirilen Katılım bankacılığı dünyada ve Türkiye'de gitgide önem kazanmaktadır. İslami Bankacılığın oluşumu ve gelişiminde ekonomik sebeplerle birlikte dini nedenler, insanların dini inançlarının, hassasiyetlerinin bankacılığa bakışı ve sosyal nedenler etkili olmuştur (Toraman, Ata ve Buğan, 2015). Dini neden olarak, İslam dininde faizin yasak olması ve bankalarda uygulanan, kredi faizi ve mevduat faizi olarak isimlendirilen faiz türlerinin haram olduğu konusunda İslam hukukçuları arasında görüş birliğinin olması etkilidir (Özsoy, 1987). Ekonomik neden olaraksa, İslami ekonominin ekonomik açıdan vadettiği konuların diğer ekonomik sistemlere göre farkı sosyo ekonomik adalete, manevi değerlere, kardeşlik ve yardımseverliğe vurgu yapmasıdır. Bankacılık sistemi sadece ekonomik amaç değil aynı zamanda sosyal adaleti sağlamanın bir aracı olarak görülmektedir (Chapra, 1985). Türkiye'de Katılım Bankacılığının tarihi 30 yıl öncesinde başlamıştır. Türkiye'de şu an faaliyet gösteren 6 Katılım Bankası vardır. Bunlar; Albaraka Türk, Bank Asya, Kuveyt Türk ve Bank Asya, Ziraat Katılım ve Vakıf Katılım Bankalarıdır. Katılım Bankacığı sektörüne 2015'te katılan iki yeni banka olan Ziraat Katılım ve Vakıf Katılım bankaları şubeleşme aşamasındadır. Katılım Bankaları faizsiz fon toplama ve fon kullandırma yöntemleri geliştirmektedir. 
Müşterilerinin bankacılık ihtiyaçlarına yönelik hizmetler sunmayı hedefleyen Katılım bankalarında kullanılan bankacılık ürünleri, müşterilerine sunulmadan önce Danışma Kurulu(Sharia Board) tarafından katılım bankacılığı prensiplerine uygunluğu incelenmektedir.

\section{Kredi Limit Tahsis ve Kullandırım Süreci}

\subsection{Kredi}

Krediyi kısaca firmaların(tüzel kişilerin) tüketicilerin(gerçek kişi) belirli bir süreliğine, bir maliyet karşıllğında bankalardan veya finansman sağlayan kuruluşlardan ödünç para kullanması olarak tanımlayabiliriz. Diğer bir ifadeyle bankaların topladıkları fonları fon talep eden şahıs ya da firmalara bir maliyet karşılığında kullandırmasıdır. Kredi ekonomik hayatta önemli bir yer tutar ve kredi olanağı olmayan finansal piyasa düşünülemez. Ekonomi içerisinde bulunan firmalar, faaliyetlerini sağlıklı bir şekilde sürdürebilmek için ihtiyaçlarına göre kredi kullanırlar (Kaan Balkaş, 2004).

\subsection{Kredi Limit Tahsis Süreci}

Bankalar kredi kullandırırken, müşterilerinin kredi borçlarını taahhüt ettikleri zamanda ödeyebileceklerinden emin olmak isterler. $\mathrm{Bu}$ sebeple bankalar finansman başvurusunda bulunan müşterilerinin talep ettikleri finansmanı ödeyebilme kabiliyetlerini ölçerler. Bu süreç Katılım ve Mevduat bankalarında benzer olmakla birlikte, Katılım bankaları müşterinin borcunu geri ödeme kabiliyetiyle birlikte, kredinin hangi ürün veya hizmetin finansmanı için kullanılacağını da önemser. Finansmanın kullanılacağı ürün veya hizmet, İslami prensiplere uygun olmas1 gerekmektedir.

\subsubsection{Tüketici Kredileri Limit Tahsis Süreci}

Tüketici kredilerinde kredi limit tahsisi her başvurulan finansman talebi için ayrı değerlendirilir ve tahsis edilen limit sadece başvuru yapılan finansman için kullanılabilir. Örneğin; bankalar, ev alımı için kredi kullanmak isteyen müşterisinin başvurusunu değerlendirir, olumlu ya da olumsuz karar verir. Aynı müşteri araç almak için kredi başvurusunda bulunduğunda ayrıca tekrardan değerlendirmeye alınır. Bankalar limit tahsisi için; müşterinin gelir durumu, KKB kredi skor puanı, başvurduğu finansman türü, teminat şartları, diğer bankalardaki riskleri gibi faktörleri dikkate alarak karar verirler.

\subsubsection{Tüzel Kişi Kredileri Limit Tahsis Süreci}

Tüzel kişi limit tahsis süreci tüketicilerden biraz farklı işlemektedir. Tahsis çalışması her bir finansman başvurusu için değil, müşteri bazlı olarak değerlendirilir. Limit tahsis kararında müşterinin talep ettiği limit türü, limit tutarıyla birlikte; finansal tabloları, finansal rasyoları, 
diğer bankalarda devam eden kredi riskini gösteren Merkez Bankası memzuç kayıtları, faaliyet gösterdiği sektör, firma ve firma ortaklarıyla ilgili edinilen referans bilgileri değerlendirmede dikkate alınan önemli faktörlerdir. Bankalar müşterilerine limit açarken bazı teminat şartlarıyla limit tahsisi yaparlar. Tüzel kişilere açılan limitler bir yıl süreyle geçerlidir ve firmalar kredi ihtiyacı olduğunda açılan limitlerinden teminat şartlarını yerine getirdiği sürece kredi kullanabilirler.

\subsection{Tüketicilere Kullandırılan Krediler}

Türkiye'de tüketiciler(gerçek kişi) krediyi ağırlıkla ev ve araç finansmanı için kullanmaktadır. Bununla birlikte eğitim, seyahat, acil nakit ihtiyacı gibi sebeplerle de bankalardan kredi talebinde bulunmaktadırlar. Katılım bankaları kredi kullandırırken ağırlıklı olarak İslami finansman yöntemlerinden "murabaha" ile finansman sağlarlar. Bu yöntemle kredi talebinde bulunan müşterisine ihtiyacı olan mal veya hizmeti satın alıp, vadeli olarak, üzerine kar ekleyerek müşterisine satmak kaydıyla finansman sağlarlar. Katılım bankalarından finansman talep eden müşteri, finansmanı kullanacağı mal veya hizmeti bildirmesi gerekmektedir. Belirtilen mal veya hizmet katılım bankacılığı prensiplerine uygun görülürse kredi verme işlemine başlanabilir. Tüketici kredilerinin kullanım amacına göre dağılımında, katılım ve mevduat bankaları arasında farklılıklar gözlenmektedir. Katılım bankaları ağırlıklı olarak konut finansmanı ve araç finansmanı kullandırırken, mevduat bankaları ihtiyaç(nakit kredi) finansmanı sağlamaktadır.

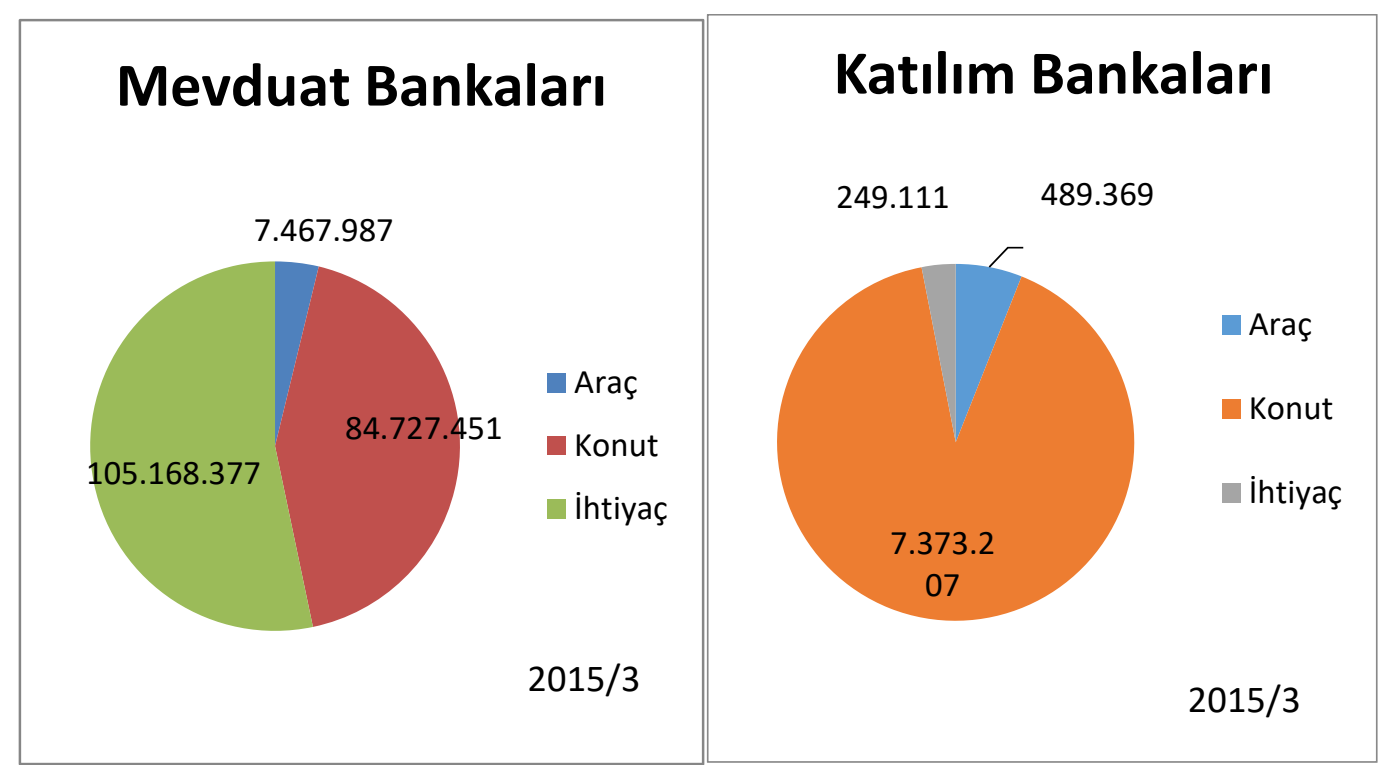

Şekil:1 Katılım ve Mevduat Bankalarında Tüketici Kredileri Dağılımı

Şekil 1'e göre mevduat bankalarında tüketicilere kullandırılan kredilerin \%50 den fazlası ihtiyaç kredisi olarak kullanılmıştır. Katılım bankalarında tüketici finansmanının büyük kısmı konut kredilerinde ve çok az kısmı ihtiyaç kredilerinde kullandırılmıştır (BDDK, 2015). 


\subsection{Tüzel Kișilere Kullandırılan Krediler}

Firmalar, faaliyetlerini sağlıklı bir şekilde sürdürmek, üretimlerini artırmak, yeni yatırımlar yapmak amacıyla kredi talebinde bulunurlar. Ticari firmaların kullandığı kredileri 3 farklı şekilde sınıflandırabiliriz. 1.Kredinin geri ödeme sıklığına göre; spot krediler ve rotatif krediler. Spot krediler kredi kullandırım aşamasında belirlenen faiz oranının kredi bitişine kadar geçerli olduğu kredilerdir. Rotatif krediler ise firmalara belirlenen limitlere göre sürekli kredi kullanan ve kredi ödemesi yapılan, kullanılabilir limitin sürekli değiştiği kredi türüdür. 2. Teminat şartlarına göre açık krediler(teminatsız krediler), teminatlı krediler olarak sınıflandırabiliriz. Açık krediler, kredibilitesi yüksek, mali yapısı güçlü firmalara herhangi bir teminat alınmadan limit tahsis edilerek kullandırılan kredilerdir. Teminatlı kredileri ise kendi içinde ikiye ayırabiliriz; kefalet karşılığı krediler, maddi teminatlı krediler. Kefalet karşılığ krediler, müşteri ile kredi değerliliği yüksek kefil veya kefillerle en az iki imza karşılığında limit tahsis edilerek kullanılan kredilerdir. Maddi teminatlı krediler, müşterinin mevduatının blokeye alınarak, müşterinin çek veya senetleri, kısa sürede nakde dönebilecek emtialar ve taşınmazlar karşılığında limit tahsis edilerek kullandırılan kredilerdir. 3. Kredinin niteliğine göre nakit ve gayri nakit krediler olarak sınıflandırabiliriz. Nakdi krediler, faiz ve komisyon karşılığında belirli bir vadeye bağlı olarak nakit kullanılan kredilerdir. Gayrinakdi krediler ise bir malın teslimi, bir işin yapılabilmesi, bir borcun vadesinde ödenmesi gibi yükümlülüklerin yerine getirilmemesi durumunda belirlenen tutarın kayıtsız şartsız ödeneceğinin taahhüt edildiği kredi türüdür (Acar, 2012).

\subsection{Kredi Faiz(Kar) Oranlarının Belirlenmesi}

Kredi arz ve talebinin bir araya geldiği kredi piyasasında, kredi talep eden kredi maliyetini minimize etme eğilimindedir. Bu motivasyonda olan kredi talepçisi en düşük faiz (kar) oranını sunan finans kurumunda kredi kullanmayı tercih eder. Bankalarda daha fazla müşteriye daha fazla kredi kullandırmayı hedefler. Bunu sağlamak için maliyet, vade vb faktörleri dikkate alarak kredi faiz(kar) oranlarını düşürme eğilimindedir. Faiz ornlarını etkileyen başlıca faktörleri; para arzı, para talebi, tasarruf miktarı, vergi oranları, yatırımlar, kamu harcamaları olarak sayabiliriz. Katılım bankaları da kredi kar oranlarını belirlerken mevduat bankalarına paralel olarak benzer faktörleri dikkate almaktadır.

\section{Literatür taraması}

Mevduat bankaları ve Katılım bankalarının çeşitli yönlerden karşılaştırıldığı bazı çalışmalar yapılmıştır. Bu çalışmalardan bazıları; Buğan(2015)Mevduat bankalarının ve Katılım bankalarının kaynaklarını etkin kullanımları karşılaştırdığı çalışmasında, Veri 
Zarflama Modeli'ni kullanmış. Toplam mevduat, faiz giderleri, faiz dışı giderler girdi, kredi alacakları, faiz gelirleri, faiz dışı gelirler çıktı veri seti ile yaptığı çalışmanın sonucunda Katılım bankalarının kaynaklarını daha etkin kullandığı sonucuna varmıştır. Diğer bir çalışmada, Dağ(2011) Mevduat Bankalarıyla Katılım bankalarının toplam verimlilik indeksinin karşılaştırmıştır. Veri Zarflama Modeli'nin kullanıldığı çalışmada Mevduat toplamı, toplanan fonlar, faiz giderleri, kar payı giderleri, personel giderleri girdi olarak, krediler, plasman toplamı, kullandırılan fonlar, faiz gelirleri, kar payı gelirleri, net ücret ve komisyon gelirleri çıktı veri olarak kullanılmıştır. Sonuç olarak katılım bankalarının daha iyi değerlere sahip olduğu tespit edilmiştir. Sakarya ve Kaya(2013) Katılım ve mevduat bankalarının, iş modelleri, likidite, etkinlik, aktif kalitesi, kredi riski, karlılık verileriyle panel veri yöntemi kullanarak yaptığı çalışmada katılım bankalarının mevduat bankalarına oranla daha yüksek öz kaynakla ve daha düşük kaldıraçla faaliyet gösterdiği sonucuna varmışlardır. Katılım ve mevduat bankalarının finansal rasyolarının karşılaştırıldığı çalışmada, Parlakkaya ve Çürük(2011) karlılık ve likidite oranlarının bir birinden ayırt edici özellikte olduğu ve operasyonel faaliyetlerinin farklılık gösterdiği, katılım bankalarının Pazar payının düşük olmasının fon toplama ve kredi kullandırma faaliyetlerinin yeterli düzeyde olmamasının sonucu olduğunu belirtmişlerdir.

Son yıllarda popüler olan bir konu olan Katılım Bankacılığı ile ilgili dünyanda farklı çalışmalara rastlanmıştır. Loghod(2011) 2000-2005 yılları arasında karlılık ve likidite verileriyle Bahreyn, Kuveyt, Katar, Suudi Arabistan, Birleşik Arap Emirlikleri'nde faaliyet gösteren Katılım ve Mevduat bankalarının finansal performansları karşılaştırmıştır. Bu çalışma neticesinde karlılık açısından ciddi bir farklılığın olmadığı görülmüştür. Katılım bankalarının daha az likidite riski aldığı, mevduat bankalarının dış borca daha çok bağımlı olduğu tespit edilmiştir. Diğer bir çalışmada, 21 ülkeden 43 Katılım bankası ve 37 Mevduat bankaları maliyet ve kar verimliliği açısından incelenmiştir. Bu çalışma sonucunda Mohamad, Hassan, Bader(2009) Katılım ve Mevduat bankaları arasında kayda değer bir farklılığın olmadığı tespit etmişlerdir. Ayrıca hem Katılım hem Mevduat bankaları için maliyetlerin minimize edilmesi için hala potansiyel olduğu belirtilmiştir. Kakakhel, Raheem, Tariq(2010) Pakistan'da faaliyet gösteren 2 Katılım bankası ve 2 Mevduat bankasının performanslarını karşılaştırmışlardır. 2008-2010 yılları arasında, likidite, karlılık, ödeme gücü için finansal rasyo analiziyle test edilmiştir. Sonuç olarak Pakistan'da mevduat bankalarının daha karlı olduğu gözlenmiştir. Yapılan literatür taramasında, Katılım Bankaları ve Mevduat Bankalarının, NPL rasyolarını karşılaştıran herhangi bir çalışmaya rastlanmamıştır. 


\section{Veri Seti ve Araştırma Yöntemi}

\subsection{Veri Seti}

$\mathrm{Bu}$ çalışmada katılım ve mevduat bankalarının faiz/kar oranları ve NPL rasyoları arasındaki ilişki incelenmektedir. Bu sebeple Türkiye de faaliyet gösteren mevduat ve katılım bankalarının hepsi dâhil edilmiştir. 2005-2015 tarihleri arasında Katılım bankalarının kar oranları ve NPL rasyoları, Mevduat Bankalarının Kredi faiz oranları ve NPL rasyoları kullanılmıştır. Veriler aylık olarak E-views'te Korelasyon, Birim Kök Testleri, VAR, Granger Nedensellik testleri kullanılarak incelenmiştir. Veriler BDDK, Merkez bankası ve Katılım Bankalarının resmi sitelerinden temin edilmiştir.

\subsection{Korelasyon Analizleri}

\subsubsection{5-2015 Verileri Kullanılarak Yapılan Korelasyon Analizleri}

Katılım bankaları kar oranları, mevduat bankaları faiz oranları, katılım bankaları NPL rasyoları ve mevduat bankaları NPL rasyolarının 2005 ve 2015 yılları arasındaki verileri kullanılarak, verilerin birbiriyle olan ilişkileri korelasyon analiziyle incelenmiştir.

Tablo: 1 Korelasyon Matrisleri

KAR FAIZ

\begin{tabular}{lll}
\hline \hline KAR & 1.000000 & 0.933867 \\
FAIZ & 0.933867 & 1.000000 \\
& & \\
& KATILIMNPL & KAR \\
\hline \hline
\end{tabular}

\begin{tabular}{lll}
\hline KATILIMNPL & 1.000000 & 0.245715 \\
KAR & 0.245715 & 1.000000
\end{tabular}

KATILIMNPL MEVDUATNPL

\begin{tabular}{lll}
\hline \hline KATILIMNPL & 1.000000 & 0.660261 \\
MEVDUATNPL & 0.660261 & 1.000000
\end{tabular}

\begin{tabular}{ccc} 
& FAIZ & MEVDUATNPL \\
\hline \hline FAIZ & 1.000000 & 0.210815 \\
MEVDUATNPL & 0.210815 & 1.000000 \\
Kar oranları ve NPL rasyoları & arasinda 0.24 oranında pozitif yönlü korelasyon iliskisi
\end{tabular}

Kar oranları ve NPL rasyoları arasında 0.24 oranında pozitif yönlü korelasyon ilişsisi vardır. Faiz oranlarıyla NPL rasyoları arasında 0.21 oranında pozitif yönlü korelasyon ilişkisi olmakla beraber Katılım bankalarında kar oranı ve NPL rasyolarına göre daha düşük bir korelasyon ilişkisi vardır. Katılım ve Mevduat bankaları NPL rasyoları arasında 0.66 oranında 
pozitif yönlü korelasyon ilişkisi vardır. Kar oranları ve faiz oranları arasında 0.93 oranında pozitif yönlü korelasyon ilişkisi vardır.

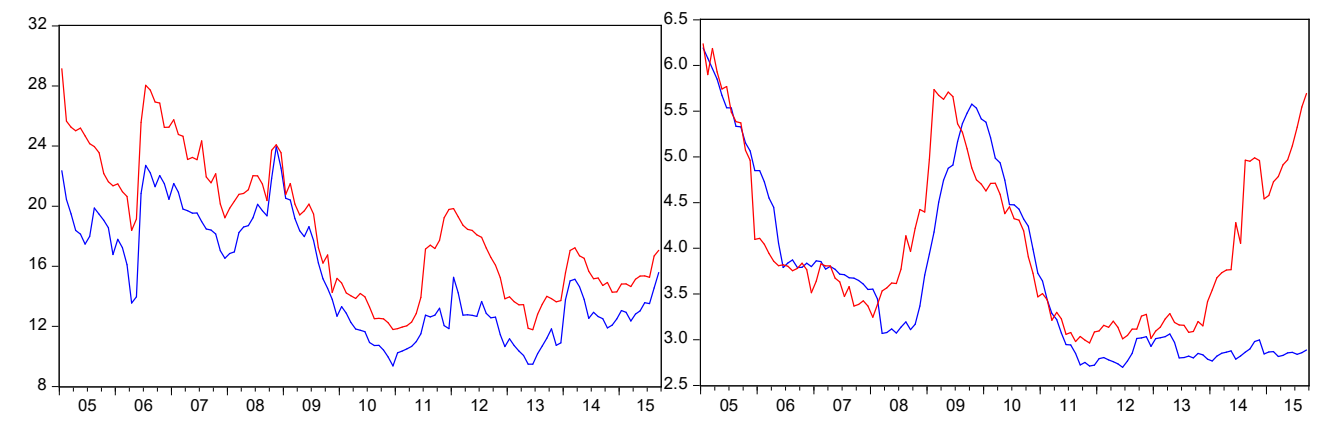

Grafik 1: Faiz ve Kar Grafiği $\quad$ Grafik 2: Mevduat ve Katılim NPL Grafiği

Grafik 1'de görüleceği gibi 2005-2015 yılları arasında kar oranları faiz oranlarından daha yüksek seyretmektedir. Grafik 2'de görüleceği üzere 2013 itibariyle Katılım Bankaları NPL rasyolarında normalin dışında bir artış göstermektedir. Bu artışın önemli sebeplerinden birisi Katılım Bankacılığg sektörünün en büyük bankalarından olan Bank Asya ile ilgili olumsuzluklardan kaynaklanmaktadır. Daha sağlıklı bir sonuç elde etmek amacıyla çalışmamıza 2013 sonrası veriler çıkarılarak devam edilmiştir.

\subsubsection{5-2012 Verileri Kullanılarak Yapılan Korelasyon Analizleri}

Katılım bankaları kar oranları, mevduat bankaları faiz oranları, katılım bankaları NPL rasyoları ve mevduat bankaları NPL rasyolarının 2005 ve 2012 yı1ları arasındaki verileri kullanılarak, verilerin birbiriyle olan ilişkileri korelasyon analiziyle incelenmiştir.

Tablo: 2 Korelasyon Matrisleri

KATILIMNPL MEVDUATNPL

\begin{tabular}{llr}
\hline KATLMNPL & 1.000000 & 0.883819 \\
MEVDUATNPL & 0.883819 & 1.000000
\end{tabular}

FAIZ

KAR

\begin{tabular}{lll}
\hline \hline FAIZ & 1.000000 & 0.917301 \\
KAR & 0.917301 & 1.000000 \\
& & \\
& KATILIMNPL & KAR \\
\hline \hline
\end{tabular}

\begin{tabular}{llr}
\hline \hline KATLMNPL & 1.000000 & 0.276638 \\
KAR & 0.276638 & 1.000000
\end{tabular}




\begin{tabular}{lll}
\hline \hline FAIZ & 1.000000 & 0.210815 \\
MEVDUATNPL & 0.210815 & 1.000000
\end{tabular}

Katılım bankaları NPL rasyoları ve Mevduat bankaları NPL rasyoları arasında, 2013 ve sonrasının dahil olduğu verilerle 0.66 oranında pozitif yönlü korelasyon ilişkisi vardı, 2012 ve öncesinin verileriyle 0.88 oranında pozitif yönlü korelasyon ilişkisi vardır. Kar oranları ve faiz oranları arasında 0.91 oranında pozitif yönlü korelasyon ilişkisi vardır. Bunun sebebi olarak her ne kadar prensipler ve işleyiş açısından farklılıklar olsa da, aynı piyasada varlığını sürdüren, aynı piyasada müşterilerine finansman sağlayan Katılım ve Mevduat Bankaları, kredi maliyetlerini benzer faktörlere göre belirlemesidir. Kar oranı ve Katılım Bankaları NPL rasyoları arasında 0.27 oranında pozitif yönlü korelasyon ilişkisi vardır. Faiz oranı ve Mevduat Bankaları NPL rasyoları arasında 0.21 oranında pozitif yönlü korelasyon ilişkisi vardır.

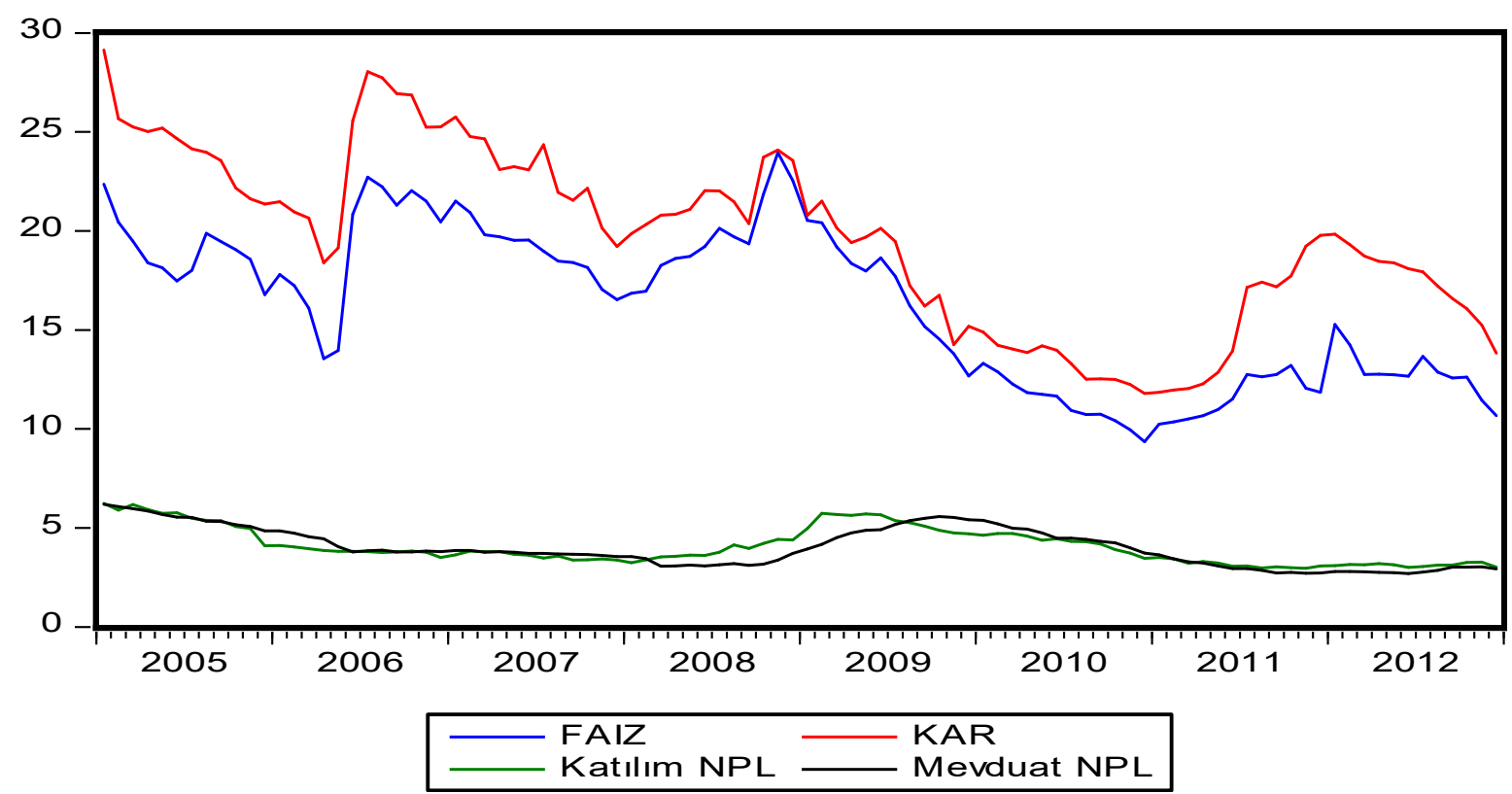

Grafik 3: Faiz, Kar, Mevduat ve Katılım NPL

Katılım ve Mevduat Bankalarının NPL rasyoları arasındaki korelasyon, grafik 3 'te net olarak görülmektedir. Benzer şekilde faiz ve kar oranları arasında korelasyon analizinde çıkan güçlü korelasyonu grafikte görülmektedir. Katılım bankaları kar oranları 2005-2012 yılları arasında Mevduat bankaları faiz oranlarına göre daha yüksek seyretmektedir ancak NPL rasyoları bazı dönem Katılım Bankalarında, bazı dönem Mevduat Bankalarında daha yüksek olduğu görülmektedir. 


\subsubsection{Kar, Faiz, NPL Verilerinin Aylık Yüzdesel Değişimleriyle Yapılan Korelasyon Analizleri}

Katılım bankaları kar oranları, mevduat bankaları faiz oranları, katılım bankaları NPL rasyoları ve mevduat bankaları NPL rasyolarının yüzdesel değişimleri alınarak, verilerin birbiriyle olan ilişkileri korelasyon analiziyle incelenmiştir.

Tablo:3 Korelasyon Matrisleri

\begin{tabular}{lll} 
& DFAIZ & DKAR \\
\hline \hline DFAIZ & 1.000000 & 0.691969 \\
DKAR & 0.691969 & 1.000000
\end{tabular}

DKATILIMNPL DMEVDUATNPL

\begin{tabular}{lll}
\hline \hline DKATILIMNPL & 1.000000 & 0.336785 \\
DMEVDUATNPL & 0.336785 & 1.000000 \\
& & \\
& DKAR & DKATILIMNPL \\
\hline \hline
\end{tabular}

\begin{tabular}{lll}
\hline \hline DKAR & 1.000000 & 0.083557 \\
DKATILIMNPL & 0.083557 & 1.000000
\end{tabular}

DKATILIMNPL $\quad 0.083557 \quad 1.000000$

DFAIZ DMEVDUATNPL

\begin{tabular}{lrr}
\hline \hline DFAIZ & 1.000000 & -0.114210 \\
DMEVDUATNPL & -0.114210 & 1.000000
\end{tabular}

Aylık kar oranlarındaki yüzdesel değişimle, aylık Katılım Bankalarının NPL rasyoları arasında 0.08 oranında pozitif yönlü korelasyon ilişkisi vardır. Aylık faiz oranlarındaki yüzdesel değişimle, aylık Mevduat Bankalarının NPL rasyoları arasında 0.11 oranında negatif yönlü korelasyon ilişkisi vardır.

\subsubsection{3 öncesi NPL ve Kar/Faiz Farkları Arasındaki Korelasyon Matrisi}

Katılım bankaları kar oranları/mevduat bankaları faiz oranları farkının ve katılım bankaları NPL rasyoları/mevduat bankaları NPL rasyoları farkının birbiriyle olan ilişkileri korelasyon analiziyle incelenmiştir.

Tablo:4 Korelasyon Matrisleri

FARKKAR

1.000000

$-0.156803$
FARKNPL

$-0.156803$

1.000000 
Kar oran1-faiz oran1, katılım bankaları NPL rasyoları -Mevduat bankaları NPL rasyoları farkları arasında 0.15 oranında negatif yönlü korelasyon ilişkisi vardır.

\subsection{VAR, Granger Nedensellik, Etki Tepki Analizleri}

İktisadi ilişkilerin karmaşıklığı, birçok iktisadi olayın tek denklemli modeller yerine, eşanlı denklemler yardımıyla incelenmesine yol açmıştır. İktisadi hayatta, makroekonomik değişkenlerin karşılıklı olarak birbirlerinden etkilendikleri gözlenmektedir. Bu nedenle verileri salt içsel ya da dışsal değişken olarak ayırmak zorlaşmaktadır. Eşanlı denklem sistemlerinde, içsel-dışsal değişken ayrımı gibi güçlüklerin çözümüne yönelik olarak öne sürülmüş olan Vektör Otoregresif Modeller (VAR) ile bu zorluk aşılmaktadır. Ayrıca yine eşanlı denklem sistemlerinde, belirlenme problemini aşabilmek için bazen yapısal model üzerinde bazı kisitlamalar yapmak gerekmektedir (Darnell,1990).

Sözü edilen bu kısıtlamalar araştırma için birtakım güçlükler doğurmaktadır. VAR modelleri ise; yapısal model üzerinde herhangi bir kısıtlama getirmeksizin dinamik ilişkileri verebilmekte ve bu sebeple zaman serileri için sıklıkla kullanılmaktadır (Keating,1990). Zaman serileri üzerinde yapılan ekonomik çalışmalarda çok kullanılan, VAR modeli, herhangi bir iktisat teorisinden yola çıkarak, değişkenlerin içsel-dışsal ayrımını gerektirmediği için, bu yönüyle eşanlı denklem sistemlerinden ayrılmaktadır (Wojciech ve Derek, 1992). Ayrıca VAR modellerinde bağımlı değişkenlerin gecikmeli değerlerinin yer alması, geleceğe yönelik güçlü tahminlerin yapılmasını mümkün kılmaktadır (Kumar,Leona,Gasking, 1995).

İktisat teorisinde değişkenler arasındaki ilişkinin belirlenmesi ve test edilmesi, öncelikle değişkenlerin içsel mi yoksa dışsal mı olduğunun belirlenmesine bağlıdır. Granger (1969), Sims (1972), bu tür ilişkilerden yola çıkarak, nedenselliği öne sürmüşlerdir (Granger,1980). Eğer iki zaman serisi karşılıklı olarak birbirlerinin sebebi ise, nedensellik karşılıklı olacak ve bir feedback ilişki meydana gelecektir (Granger ve Newbold,1986). Bu ilişkiyi araştırmak üzere aşağıdaki model ileri sürülmüştür;

$$
\begin{aligned}
& \mathrm{yt}=\Sigma \alpha_{\mathrm{i}} \mathrm{y}_{\mathrm{t}-\mathrm{i}}+\Sigma \beta_{\mathrm{i}} \mathrm{x}_{\mathrm{t}-\mathrm{i}}+\mathrm{u}_{1 \mathrm{t}} \\
& \mathrm{xt}=\Sigma \alpha_{\mathrm{i}} \mathrm{x}_{\mathrm{t}-\mathrm{i}}+\Sigma \beta_{\mathrm{i}} \mathrm{y}_{\mathrm{t}-\mathrm{i}}+\mathrm{u}_{2 \mathrm{t}}
\end{aligned}
$$

Model, sadece gecikmeli değerler üzerine kurulmuş bir yapıda olup, eğer, $\beta \mathrm{i}=0$ ise, $x t$, yt'nin granger nedeni olamayacaktır (Maddala, 1989).

VAR modelinin tahmin edilmesi neticesinde, elde edilen parametreleri yorumlamak yerine, sistemin tahmini neticesinde elde edilen artıkların analizine geçilerek, geleceğe yönelik yorumlar yapılabilir. Modelde yer alan değişkenlerin hata terimlerinde meydana gelecek 


\section{H. Kolukisa}

şokların, diğer değişkenler üzerindeki etkisi, Impulse-Response (Etki-Tepki) fonksiyonları ile ölçülmektedir. Enders(1995)'de ifade edildiği gibi, modelin tahmini ile belirlenen ve öngörü hata varyansını ölçen Variance Decomposition (Varyans Ayrıştırması), artıkların analizinde kullanılan bir diğer tekniktir. Sözü edilen teknik yardımı ile istatistiki şokların değişkenler üzerindeki etkileri görülmüş olacaktır. Bir değişkenin hata teriminde meydana gelecek şokun diğer değişkenler tarafından açıklanma oranı hesaplanarak, değişkenler arasındaki iktisadi ilişkiler daha iyi açıklanabilecektir. Eğer bir değişkenin hata terimine ilişkin şok, diğer değişkenin ileriye yönelik tahmin hatası varyansını açıklayabiliyor ise, ilgili değişken içsel olarak değerlendirilebilir (Lütkepohl,1993).

\subsubsection{Birim Kök Testleri}

VAR modelleri ile işlem yapabilmek için öncelikle serilerin durağan olmaları gerekmektedir. Zaman içinde serilerin ortalaması ve varyansının sabit olmasını ifade eden durağanlık kavramı, bu amaçla en yaygın olarak kullanılan, Augmented Dickey-Fuller (1979:427-431) testleri ile incelenmiştir.

Tablo:5 Augmented Dickey Fuller

Sıfir Hipotezi: KAR Birim kök var

Eksojen: Sabit

Gecikme Uzunluğu: 0 (Otomatik - Schwarz Bilgi kriterine göre, maxgecikme=11)

\begin{tabular}{lllc}
\hline \hline & & t-istasitik & p-olasıllı̆̆ \\
\hline \hline Genişletilmiş Dickey-Fuller test istatistik & & -1.925022 & 0.3196 \\
\hline Test kritik değerleri: & $1 \%$ düzey & -3.500669 & \\
& $5 \%$ düzey & -2.892200 & \\
& $10 \%$ düzey & -2.583192 & \\
\hline \hline
\end{tabular}

Sıfır Hipotezi: FAIZ birim kök var

Eksojen: Sabit

Gecikme Uzunluğu: 2 (Otomatik - Schwarz Bilgi kriterine göre, maxgecikme =11)

\begin{tabular}{llll}
\hline \hline & & t-istatistik & p-olasılığ1 \\
\hline \hline Genişletilmiş Dickey-Fuller test istatistik & & -1.196561 & 0.6733 \\
\hline Test kritik değerleri: & $1 \%$ düzey & -3.502238 & \\
& $5 \%$ düzey & -2.892879 & \\
& $10 \%$ düzey & -2.583553 & \\
\hline \hline
\end{tabular}

Sifır Hipotezi: KATLMNPL birim kök var

Eksojen: Sabit

Gecikme Uzunluğu: 1 (Otomatik - Schwarz Bilgi kriterine göre, maxgecikme =11)

\begin{tabular}{lllc}
\hline \hline & & t-istatistik & p-olasıllı̆ 1 \\
\hline \hline Genişletilmiş Dickey-Fuller test istatistik & & -1.763649 & 0.3963 \\
\hline Test kritik değerleri: & 1\% düzey & -3.501445 & \\
& 5\% düzey & -2.892536 &
\end{tabular}


*MacKinnon (1996) tek-taraflı p-değerleri.

Sıfır Hipotezi: MEVDUATNPL birim kök var

Eksojen: Sabit

Gecikme Uzunluğu: 3 (Otomatik - Schwarz Bilgi kriterine göre, maxgecikme =11)

\begin{tabular}{llcc}
\hline \hline & & t-istatistik & p-olasilığ \\
\hline \hline Genişletilmiş Dickey-Fuller test istatistik & & -2.463917 & 0.1277 \\
\hline Test kritik değerleri: & $1 \%$ düzey & -3.503049 & \\
& $5 \%$ düzey & -2.893230 & \\
& $10 \%$ düzey & -2.583740 & \\
\hline \hline
\end{tabular}

*MacKinnon (1996) tek-taraflı p-değerleri.

Birim kök testi sonuçlarına göre değişkenlerin düzey değerlerine ait ADF istatistiklerinin mutlak değerleri, \%1 anlamlılık düzeyindeki MacKinnon kritik değerlerinin mutlak değerlerinden küçüktür. Kar, Faiz, Katılım bankaları NPL rasyoları, Mevduat bankaları NPL rasyoları verileri durağan değildir. Verilerin değişimleri alınarak yapılan birim kök testi sonuçlarında Kar, Faiz, Katılım bankaları NPL rasyoları durağan, Mevduat bankaları NPL rasyoları durağan değildir. Mevnpl verisinin logaritmasını ve sonrasında değişimi alınarak yapılan birim kök testlerinde durağan çıkmıştır. Faiz, kar, katnpl I(1) mevnpl I(2). Veriler aynı dereceden durağan olmadığg için cointegrasyon testleri yapılmamıştır. Veriler durağan olduktan sonra VAR analizi yapılmıştır.

\subsubsection{Faiz, Mevduat NPL rasyolarıyla VAR, Granger Nedensellik, Etki Tepki Analizleri}

Denklem sisteminde yer alan değişkenler için ortak gecikme uzunluğunu belirlemede literatürde sıklıkla kullanılan kriterler mevcuttur. Bu kriterler, Final Prediction Error (FPE), Hannan-Quinn (HQ), Schwarz (SW), Likelihood Ratio (LR) ve Akaike Information Criteria (AIC) şeklindedir. Ancak bu kriterler farklı gecikme uzunluklarını sunabilmektedirler. $\mathrm{Bu}$ durumda hangi gecikme seviyesinin optimal olacağı konusunda çelişkiler yaşanabilir. AIC kriteri birçok durumda diğerlerine göre daha yüksek gecikme seviyesi verme eğilimindedir.

Tablo:6 Değişkenlerin gecikme seviyelerinin belirlenmesi için kullanılan kriterler

\begin{tabular}{|c|c|c|c|c|c|c|}
\hline Lag & LogL & LR & FPE & $\mathrm{AIC}$ & SC & $\mathrm{HQ}$ \\
\hline 0 & 611.1930 & NA & 0.0000000000162 & -13.49318 & $-13.38208^{*}$ & -13.44838 \\
\hline 1 & 645.1087 & $64.06299^{*}$ & 0.0000000000109 & $-13.89131^{*}$ & -13.33579 & $-13.66729^{*}$ \\
\hline 2 & 659.2179 & 25.39644 & 0.0000000000114 & -13.84929 & -12.84936 & -13.44606 \\
\hline 3 & 672.9611 & 23.51615 & 0.0000000000120 & -13.79914 & -12.35480 & -13.21669 \\
\hline
\end{tabular}




$\begin{array}{lllllll}4 & 683.1695 & 16.56027 & 0.0000000000138 & -13.67043 & -11.78169 & -12.90878 \\ 5 & 695.1337 & 18.34519 & 0.0000000000154 & -13.58075 & -11.24759 & -12.63988\end{array}$

Tablo 6'daki sonuçlar değerlendirildiğinde, Swarz bilgi kriterinin haricindeki tüm kriterlerin uygun gecikme seviyesi olarak aynı sonucu verdikleri gözlenmektedir. O halde, VAR araştırmasında en uygun gecikme olarak bir gecikme kullanılabilir. Ayrıca, Dfaiz ve dlnmevduat npl verileriyle yapılan VAR analizinde uygun gecikme $(1,1)$ aralığında gerçekleşmiştir, en küçük akaike değeri bu şekilde elde edilmiştir.

Tablo:7 VAR $(1,1)$

Vector Autoregression Tahminleri

Tarih: 01/21/16 Saat: 15:43

örneklem (düzeltilmiş): 2005M03 2012M12

Dahil edilmiş gözlem: 94 (düzeltmeden sonra)

Standart hatalar ( ) \& t-istatistik [ ]

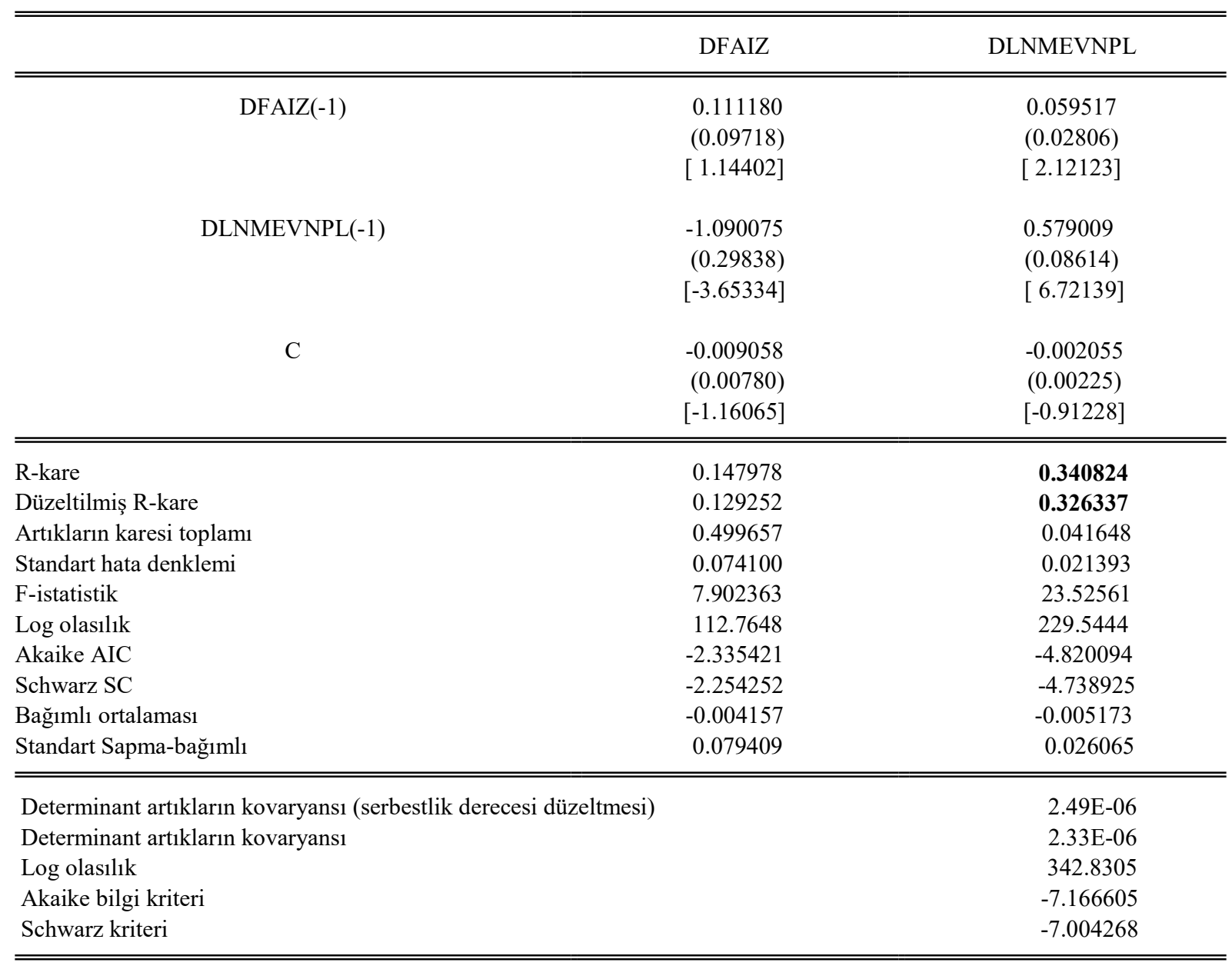

Dfaiz ve dlnmevnpl verileri için VAR analizi yapılmıştır. Tablo 7'deki sonuçlar değerlendirildiğinde, dlnmevnpl'in R-kare ve düzeltilmiş R-kare değerleri daha yüksek çıktığı için Cholesky sıralamasının dlnmevnpl değişkeni ile başlaması gerekmektedir. 
Tablo:8 Granger Nedensellik

Pairwise Granger Nedensellik Testi

Tarih: 05/06/16 Saat: 11:20

örneklem: 2005M01 2012M12

Gecikme: 2

\begin{tabular}{lcrr}
\hline \hline Sıfır Hipotezi: & Gözlem & F-istatistik & p-olasılığı \\
\hline \hline DLNMEVNPL, DFAIZ'in granger nedeni değildir & 93 & 5.79960 & 0.0043 \\
DFAIZ, DLNMEVNPL'nin granger nedeni değildir & & 3.54390 & 0.0331 \\
\hline \hline
\end{tabular}

Granger Nedensellik testi kullanarak dfaiz ve dlnmevnpl arasındaki etkileşimin yönü tespit edilmeye çalışılmıştır. Tablo 8'den elde edilen sonuçlara göre dlnmevnpl ve dfaiz değişkenleri arasında 1 gecikme için nedensel ilişkinin olduğu görülmektedir. Ho hipotezi \%5 güven aralığında reddedilmektedir. Dlnmevnpl'den dfaiz'e ve dfaiz'den dlnmevnpl'e doğru çift yönlü ve pozitif nedensellik vardır.

Bir Standart Hatalık Şoka Karşı Değişkenlerin Tepkisi
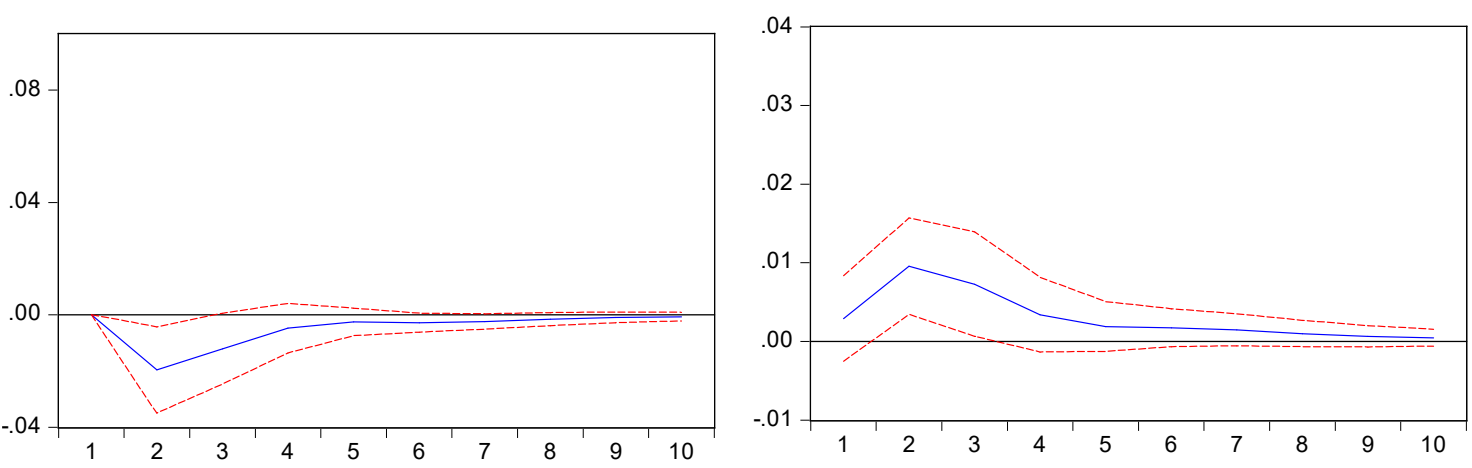

Grafik:4 DFAIZ'in DMEVDUATNPL'e Tepkisi Grafik:5 DMEVDUATNPL'in DFAIZ'e Tepkisi

Grafik 4, dlnmevnpl'de meydana gelen "bir" standart sapmalık şokun dfaiz'deki değişmeyi nasıl etkilediğini göstermektedir. Faizdeki bir standart sapmalık şokun mevnpl üzerindeki etkisi 6 aydan sonra kaybolmaktadır. Grafik 5, dfaiz'de meydana gelen "bir" standart sapmalık şokun dlnmevnpl'deki değişmeyi nasıl etkilediğini göstermektedir Mevnpl'deki bir standart sapmalık şokun faiz üzerindeki etkisi 6 aydan sonra kaybolmaktadır.

Nedensellik testinden edinilen bilgilerle tahmin edilen, iki gecikmeli VAR modelinden elde ettiğimiz varyans ayrıştırması sonuçları aşağıdaki gibidir. 
Tablo:9 Varyans Ayrışma

\begin{tabular}{|c|c|c|c|}
\hline \multicolumn{4}{|c|}{ Varyans Ayrışma DFAIZ: } \\
\hline Dönem & S.E. & DFAIZ & DLNMEVNPL \\
\hline 1 & 0.074100 & 100.0000 & 0.000000 \\
\hline 2 & 0.077859 & 91.12793 & 8.872070 \\
\hline 3 & 0.079683 & 87.49442 & 12.50558 \\
\hline 4 & 0.080221 & 86.65454 & 13.34546 \\
\hline 5 & 0.080334 & 86.50372 & 13.49628 \\
\hline 6 & 0.080353 & 86.48124 & 13.51876 \\
\hline 7 & 0.080356 & 86.47840 & 13.52160 \\
\hline 8 & 0.080356 & 86.47810 & 13.52190 \\
\hline 9 & 0.080356 & 86.47807 & 13.52193 \\
\hline 10 & 0.080356 & 86.47807 & 13.52193 \\
\hline \multicolumn{4}{|c|}{ Varyans Ayrışma DLNMEVNPL: } \\
\hline Dönem & S.E. & DFAIZ & DLNMEVNPL \\
\hline 1 & 0.021393 & 1.102904 & 98.89710 \\
\hline 2 & 0.025338 & 5.866383 & 94.13362 \\
\hline 3 & 0.026238 & 7.407382 & 92.59262 \\
\hline 4 & 0.026406 & 7.768964 & 92.23104 \\
\hline 5 & 0.026432 & 7.835837 & 92.16416 \\
\hline 6 & 0.026436 & 7.846050 & 92.15395 \\
\hline 7 & 0.026436 & 7.847368 & 92.15263 \\
\hline 8 & 0.026436 & 7.847512 & 92.15249 \\
\hline 9 & 0.026436 & 7.847525 & 92.15248 \\
\hline 10 & 0.026436 & 7.847526 & 92.15247 \\
\hline
\end{tabular}

VAR modelinin hareketli ortalamalar bölümünden elde edilen varyans ayrıştırması değişkenlerin kendilerinde ve diğer değişkenlerde meydana gelen şokların kaynaklarını yüzde olarak ifade eder. Kullanılan değişkenlerde meydana gelecek bir değişimin yüzde kaçının kendisinden, yüzde kaçının diğer değişkenlerden kaynaklandığını gösterir. Bir değişkende meydana gelen değişmelerin büyük bölümü kendisindeki şoklardan kaynaklanıyorsa, bu değişkenin dışsal olarak hareket ettiğini gösterir. Varyans ayrıştırması değişkenler arasındaki nedensellik ilişkilerinin derecesi konusunda da bilgi verir(Enders, 1995).

Tablo 9'da elde edilen sonuçlara göre, dfaiz'deki 1 standart sapmalık değişimin \%13 lük kısmı 4. dönem itibariyle dmevnpl verisindeki değişimden kaynaklanmaktadır. dmevnpl deki 1 standart sapmalık değişimin \%7'lik kısmı 3.dönem itibariyle dfaiz verisindeki değişimden kaynaklanmaktadır. 


\subsubsection{Kar, Katılım NPL rasyolarıyla VAR, Granger Nedensellik, Etki Tepki Analizleri}

VAR araştırmasında kullanılmak üzere, en uygun gecikme sayısını belirlememiz gerekmektedir. En uygun gecikme seviyesini belirlemek için tablo 10'da bilgi kriterlerine göre incelenmiştir.

Tablo:10 Değişkenlerin gecikme seviyelerinin belirlenmesi için kullanılan kriterler

\begin{tabular}{ccccccc}
\hline \hline Lag & LogL & LR & FPE & AIC & SC & HQ \\
\hline \hline 0 & 278.3608 & NA $^{*}$ & 0.00000789 & -6.073863 & $-6.018679^{*}$ & $-6.051600^{*}$ \\
1 & 282.6116 & 8.221414 & 0.00000785 & $-6.079376^{*}$ & -5.913825 & -6.012586 \\
2 & 283.7669 & 2.183631 & 0.00000836 & -6.016855 & -5.740936 & -5.905539 \\
3 & 288.8158 & 9.321036 & 0.00000817 & -6.039908 & -5.653622 & -5.884065 \\
4 & 290.7355 & 3.459633 & 0.00000856 & -5.994186 & -5.497533 & -5.793817 \\
5 & 292.0978 & 2.395254 & 0.00000908 & -5.936215 & -5.329194 & -5.691320 \\
\hline \hline
\end{tabular}

Tablo 10'daki sonuçlar değerlendirildiğinde, Final Prediction Error (FPE) Akaike (AIC) bilgi kriterleri uygun gecikme seviyesi olarak 1 göstermektedir. Ayrıca, Dkar ve dkatnpl verileriyle yapılan VAR analizinde uygun gecikme $(1,1)$ aralığında gerçekleşmiştir, en küçük akaike değeri bu şekilde elde edilmiştir. O halde, VAR araştırmasında en uygun gecikme olarak bir gecikme kullanılabilir.

Tablo:11 VAR(1,1)

Vector Autoregression Tahminleri

Tarih: 01/21/16 Saat: 15:48

örneklem (düzeltilmiş): 2005M02 2012M12

Dahil edilmiş gözlem: 95 (düzeltmeden sonra)

Standart hatalar ( ) \& t-istatistik [ ]

\begin{tabular}{|c|c|c|}
\hline & DKAR & DKATILIMNPL \\
\hline $\operatorname{DKAR}(-1)$ & $\begin{array}{r}0.205163 \\
(0.10276) \\
{[1.99657]}\end{array}$ & $\begin{array}{r}0.024394 \\
(0.06937) \\
{[0.35168]}\end{array}$ \\
\hline DKATILIMNPL(-1) & $\begin{array}{r}-0.168780 \\
(0.15526) \\
{[-1.08711]}\end{array}$ & $\begin{array}{r}0.153736 \\
(0.10480) \\
{[1.46689]}\end{array}$ \\
\hline $\mathrm{C}$ & $\begin{array}{r}-0.005866 \\
(0.00660) \\
{[-0.88933]}\end{array}$ & $\begin{array}{r}-0.005694 \\
(0.00445) \\
{[-1.27891]}\end{array}$ \\
\hline R-kare & 0.050806 & 0.024868 \\
\hline Düzeltilmiş. R-kare & 0.030172 & 0.003669 \\
\hline Artıkların karesi toplamı & 0.371205 & 0.169152 \\
\hline Standart hata denklemi & 0.063520 & 0.042879 \\
\hline F-istatistik & 2.462179 & 1.173081 \\
\hline Log olasilik & 128.5825 & 165.9155 \\
\hline Akaike AIC & -2.643841 & -3.429799 \\
\hline Schwarz SC & -2.563193 & -3.349150 \\
\hline Bağımlı ortalaması & -0.005882 & -0.006716 \\
\hline
\end{tabular}


Dkar ve dkatılımnpl verileri için VAR analizi yapılmıştır. Tablo 11'deki sonuçlar değerlendirildiğinde, dkar'ın R-kare ve Düzeltilmiş. R-kare değerleri daha yüksek çıktığı için cholesky sıralamasının dkar değişkeni ile başlaması gerekmektedir.

Tablo:12 Granger Nedensellik

\begin{tabular}{lcrr}
\hline \hline Sıfır Hipotezi: & Gözlem & F-istatistik & p-olasılığı \\
\hline \hline DKATLMNPL, DKAR'ın granger nedeni değildir & 94 & 0.56424 & 0.5708 \\
DKAR, DKATLMNPL'nin granger nedeni değildir & & 0.44331 & 0.6433 \\
\hline \hline
\end{tabular}

Granger Nedensellik testi kullanarak dkar ve dkatlmnpl arasındaki etkileşimin yönü tespit edilmeye çalışılmıştır. Tablo 12 'den elde edilen sonuçlara göre dkatlmnpl ve dkar değişkenleri arasında 1 gecikme için nedensel ilişkinin olmadığını görülmektedir, Ho hipotezi \%5 güven aralığında reddedilememektedir.

\section{Bir Standart Hatalık Şoka Karşı Değişkenlerin Tepkisi}
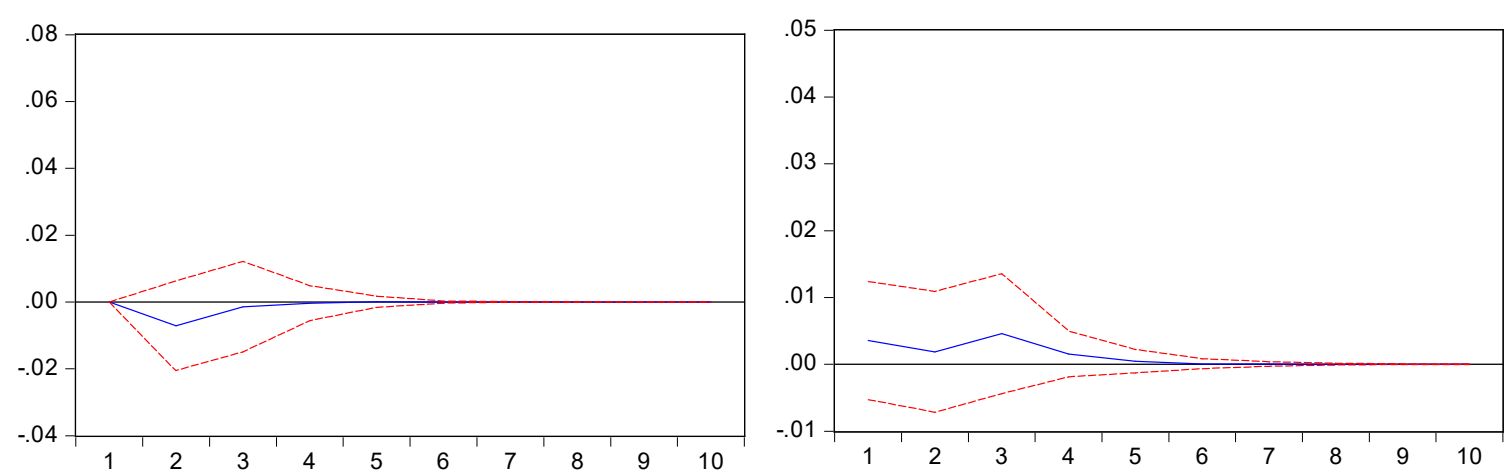

Grafik:6 DKAR'in DKATLMNPL'ye Tepkisi Grafik:7 DKATLMNPL'in DKAR'a Tepkisi

Grafik 6, dkatlmnpl'de meydana gelen "bir" standart sapmalık şokun dkar'daki değişmeyi nasıl etkilediğini göstermektedir. dkatnpl deki bir standart sapmalık şokun dkar üzerindeki etkisi 4 aydan sonra kaybolmaktadır. Grafik 7, dkar'da meydana gelen "bir" standart sapmalık şokun dkatlmnpl'deki değişmeyi nasıl etkilediğini göstermektedir. Dkardaki bir standart sapmalık şokun dkatnpl üzerindeki etkisi 4 aydan sonra kaybolmaktadır. 
Tablo:13 Varyans Ayrıştırma

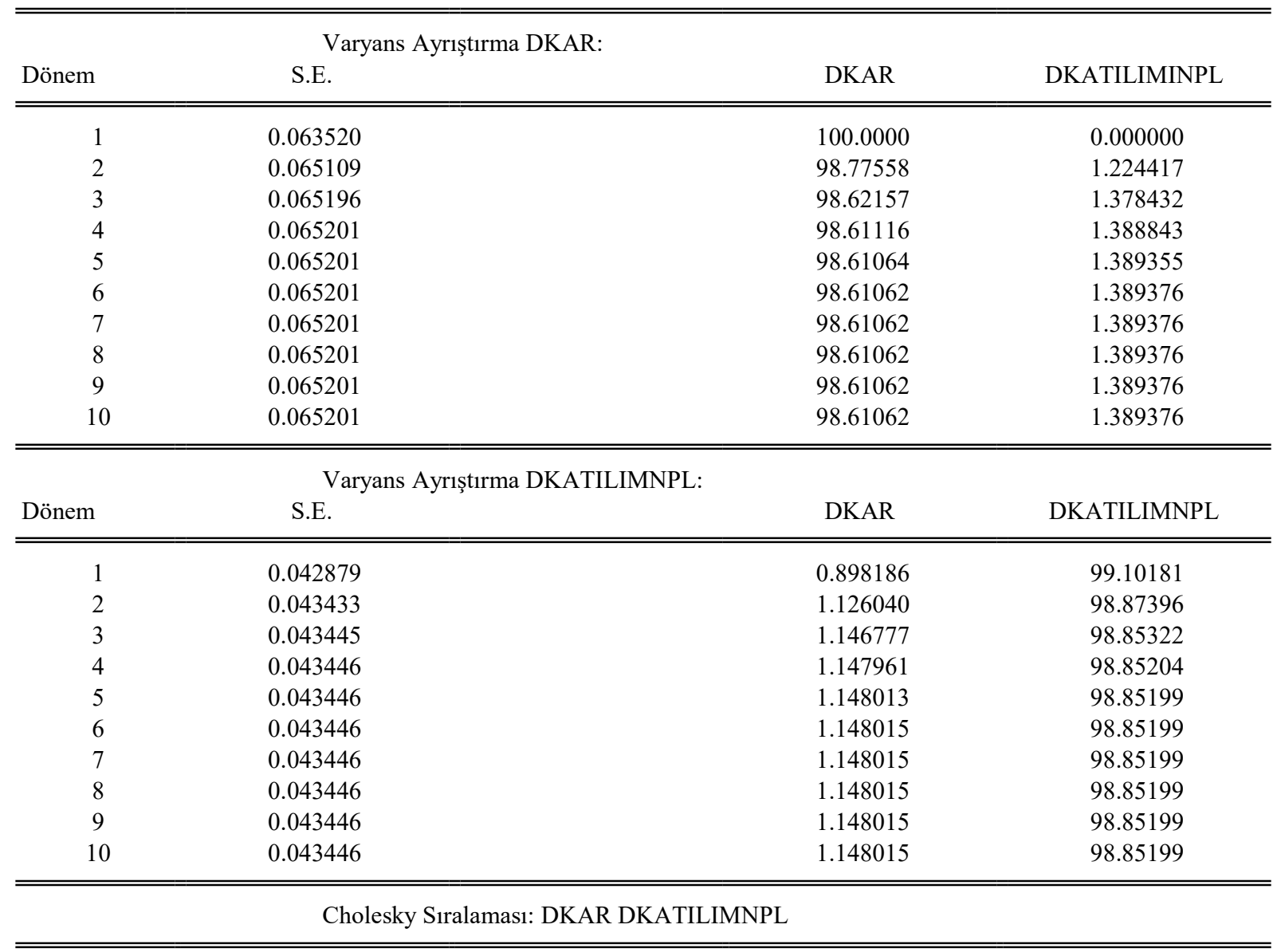

Tablo 13'te elde edilen sonuçlara göre, dkar'daki 1 standart sapmalık değişimin \%13 lük kısmı 3. Dönem itibariyle dkatnpl verisindeki değişimden kaynaklanmaktadır. Dkatnpl deki 1 standart sapmalık değişimin \%14 lük kısmı 3.dönem itibariyle dkar verisindeki değişimden kaynaklanmaktadır.

\section{Sonuç ve Değerlendirme}

Katılım ve Mevduat bankalarında; kullandırılan kredilerdeki kar oranı, faiz oranı ve takipteki kredi oranları arasındaki ilişki incelenmiştir. Katılım bankalarının kar oranları Mevduat bankalarının Faiz oranlarından daha yüksek olduğu gözlenmektedir. Bankaların istediği kredi kullanma şartları bakımından herhangi bir sorunu olmayıp finansman talebinde bulunan kişi ya da kurumların yüksek kar oranlı kredi kullandıran Katılım bankalarını, daha düşük faiz oranıyla kredi kullandıran Mevduat bankalarına tercih etmesini dini kaygılardan kaynaklandığını söylenebilir. Bankacılık sektöründe genel algı, Katılım bankaları daha yüksek kar oranlarıyla kredi kullandırdıkları için (daha düşük faiz oranlarından kredi kullandıran Mevduat bankaları tarafından finansman sağlanmayan kişi ya da kurumların, daha yüksek kar 
oranını kabul ederek Katılım Bankalarını tercih edebileceği) takipteki kredi oranlarının da daha yüksek olacağı şeklindedir.

$\mathrm{Bu}$ çalışmada; Katılım Bankalarının yüksek kar oranlarından kredi vermelerinin takipteki kredi oranlarını nasıl etkilediği, sektörde algılandığı gibi yüksek kar oranlarının takipteki kredi oranlarının artmasına sebep olup olmadığı incelenmiştir. Kar oranlarındaki değişimle Katılım Bankaları takipteki kredi oranları arasındaki yapılan korelasyon, VAR, Granger Nedensellik, analizlerinden elde edilen sonuçlara göre, kar oranlarının artması ya da azalmasıyla takipteki kredi oranları arasında doğrudan bir etkileşim olmadığı ifade edilebilir. 


\section{Kaynakça}

Adrian,C. ve A.Darnell (1990). Dictionary of Econometrics. England: Edward Elgar Pub

BDDK (2015). Türk Bankacılık Sektörü İnteraktif Aylık Bülten. 30 Aralık 2015 tarihinde http://ebulten.bddk.org.tr/ABMVC/ sayfasından erişilmiştir.

Cengiz T., H. Ali Ata ve M. F. Buğan(2015). İslami Bankacılık Faaliyetlerine Yönelik Müşteri Algısı Üzerine Bir Araştırma. Gaziantep University Journal of Social Sciences, 14(4):761-779. $\quad 30 \quad$ Mart $2016 \quad$ tarihinde http://www.tkbb.org.tr/Documents/Yonetmelikler/Gaziantep_Universitesi.pdf sayfasından erişilmiş̧tir.

Charemza, W.W. ve Derek F.D. (1992). New Directions in Econometric Practise General to Spesific Modelling, Cointegration and Vector Autoregressions. England: Edward Elgar Pub.

David A.D. ve Wayne A. F. (1979). Distribution of the Estimators for Autoregressive Time Series with a Unit Root. Journal of American Statistical Association, 74 (366), pp. $427-$ 431.

Granger, C.W.J. (1980). J. Kmenta (Ed)., Some Comments on The Role of Time Series Analysis in Econometrics. New York: James B. Ramsey Academic Press.

Granger, C.W.J. ve Paul Newbold (1986). Forecasting Economic Time Series, Economic Theory, Econometrics and Mathemathical Economics, Second Edition. New York: Harcourt Brace Jovanovich Inc.

Hadeel A. L. (2011). Do Islamic Banks Perform Better than Conventional Banks? Evidence from Gulf Cooperation Council countries. 20 Ocak 2016 tarihinde http://www.arabapi.org/images/publication/pdfs/297/297_wps1011.pdf sayfasından erişilmiştir.

İbrahim A. ve Sevda Y. (2008). Banka Kredileri ve Enflasyon Arasındaki İlişki: Türkiye Üzerine Ekonometrik Bir Analiz. 20 Ocak 2016 tarihinde http://eidergisi.istanbul.edu.tr/sayi7/iueis7m4.pdf_sayfasından erişilmiştir.

İsmail Ö. (1987). Türkiye'de Özel Finans Kurumları ve İslam Bankacılı̆̆g. İstanbul: Timaş Yayınlar1.

Kaan B. (2004). Kredi Kavramı ve Sektör Kredilerine Göre Türkiye'deki Belli Başlı Sektörlerin Analizi. 15 Aralık 2015 tarihinde http://www.tkbb.org.tr/images/Documents/YuksekLisans/BITIRME_PROJESI_KATILIM_BANKACILIGININ_TARIHI_VE_GELECE GI_OMER_EMEC.pdf)ssayfasından erişilmiştir.

Keating, J.W. (1990). Identifying VAR Models Under Rational Expectations. Journal of Monetary Economics, 25: 453 - 476.

Kumar, V. ve Leona, R.P. ve J.N Gasking (1995). Aggregate and Disaggregate Sector Forecasting Using Consumer Confidence Measures. International Journal of Forecasting, 11(3): 361-377.

Helmut L. (1993). Introduction to Multiple Time Series Analysis. Berlin: Springer -Verlag.

Gangadharrao S. M. (1989). Introduction to Econometrics. New York: Macmillan Publishing Company.

Mehmet Fatih B. (2015). Katılım Bankaları ile Konvansiyonel Bankaların Etkinliklerinin VZA ve Malmquist TFV Endeksi ile. 10 Aralı 2015 tarihinde http://www.tkbb.org.tr/documents/tezler/yukseklisans/KATILIM_BANKALARI_ILE_ KONVANSIYONEL_BANKALARIN_ETKINLIKLERININ_VZA_VE_MALMQ $\bar{Q} \overline{\text { IS }}$ T_TFV_ENDEKSI_ILE_KARSILASTIRILMASI.pdf sayfasından erişilmiştir. 
Muhammad Umer C. (1985). Towards a Just Monetary System, The Islamic Foundation. London: Leicester.

Okan A. (2012). Ticari veya Kurumsal Krediler Nelerdir? 21 Ocak 2016 tarihinde http://www.okanacar.com/2012/10/ticari-veya-kurumsal-krediler-nelerdir.html sayfasından erişilmiştir.

Ömer E. (2014). Katılım Bankacılığının Tarihi ve Geleceği. 5 Aralık 2015 tarihinde https://www.bddk.org.tr/WebSitesi/turkce/Raporlar/Bankacilikta_Yapisal_Gelismeler/1 1085bygr_2011.pdf_sayfasından erişilmiştir.

Raif P. ve Suna A. Ç. (2011). Finansal Rasyoların Katılım Bankaları ve Geleneksel Bankalar Arasında Bir Tasnif Aracı Olarak Kullanımı: Türkiye Örneği. Ege Akademik Bakış, Cilt 11(3).

Sakarya B. ve Kaya Y. (2013). Türk Bankacılık Sektöründe Katılım ve Mevduat Bankaların

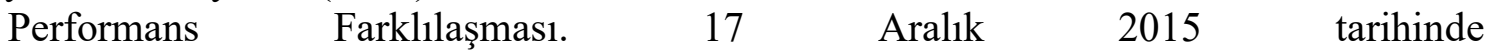
www.ekonomikyaklasim.org/eyc2013/?download=Paper\%20215.pdf sayfasindan erişilmiştir.

Shahid J. K., Faryal R. ve Muhammad T. (2010). A Study of Performance Comparison between Conventional and Islamic Banking in Pakistan. 20 Ocak 2016 tarihinde http://www.aupc.info/wp-content/uploads/2014/01/Volume-6-Issue-2-7.pdf sayfasindan erişilmiştir.

Shamsher M., Taufiq H. ve Mohamed K. B. (2010). Efficiency of Conventional versus Islamic Banks: International Evidence using the Stochastic Frontier Approach. 20 Ocak 2016 tarihinde http://citeseerx.ist.psu.edu/viewdoc/download?doi=10.1.1.453.6955\&rep=rep1\&type $=\mathrm{p}$ df_sayfasından erişilmiştir.

Sinan D. (2011). Türkiye'deki Katılım ve Mevduat Bankalarının Etkinliklerinin Veri Zarflama Yöntemiyle Karşılaştırılması. $16 \quad$ Aralı 2015 tarihinde http://www.tkbb.org.tr/Documents/Tezler/Yukseklisans/sinan_dag_tez.pdf_sayfasından erişilmiştir.

Walter E. (1995). Applied Econometric Time Series. New York: lowa State University.

Walter E. (1995). Applied Econometric Time Series:Wiley Series in Probability and Mathemathical Statistics. New York: John Wiley Inc. 


\section{Summary}

\section{Introduction}

The basic economic functions of banks are to mediate the funds they collect from depositors to those individuals or companies that demand credit which are in need of financing. Loans are one of the major areas of activity of banks. Banks aim to generate revenue for themselves and depositors by giving credit to individuals and companies. In Turkey, Participation bank's(term used for Islamic banking in Turkey) credit profit rates are higher than depozit bank's credit interest rates. It is believed that, eventhough with higher financing costs, customers who choose participation banks over to deposit banks shall have a problematic profile that has lower payment power. Therefore, it is expected that paticiptaion bank's NPL ratios would be higher than depozit bank's NPL ratios.

\section{Purpose of the Study}

In this paper, It was examined whether participation bank's high profit rates for credits affect NPL ratios. Also correlation between profit/interest rates applied for credit and NPL ratios are researched.

\section{Research Questions}

Does participation bank's profit rates applied for credits correlate with non-performing loan ratios of participation banks?

Does deposit bank's interest rates applied for credits correlate with non-performing loan ratios of deposit banks?

\section{Literature Review}

The purpose of the literature review was to see if there are supporting reseaches for the view of participation bank's high financial cost affect NPL ratios. There are several researches which compared participation banks with deposit banks from various aspects. Some researches in Turkey, resource use efficiency of participation banks and deposit banks is compared and it is determined that participation banks use resourses more effectively. Another research was compared financial ratios of participatin banks and deposit banks, it is seen that profitability and liquidity ratios are distinguished from each other and participation bank's and deposit bank's operational activities differ. As a result of research, low market share of participation banks is the result of the inadequacy of fund collection and lending activities. In a study outside Turkey, participation banks and deposit banks operating in Bahrain, Kuwait, Qatar, Saudi Arabia and United Arab Emirates are compared according to their financial performances by profitability ratios and liquidity ratios. As a result of this study, there was not significant difference in terms of profitability but participations banks have less liquidity risk and it is stated that deposit banks are more dependent on external debt. In the literature review, there was no study was found which is comparing NPL ratios of participation banks and deposit banks according to their financial costs.

\section{Data Set and Research Methodology}

In this study, the relationship between interest/profit ratios and NPL ratios of participation banks and deposit banks are examined. For this matter, all participation banks and deposit banks which are operating in Turkey were included. As data; monthly profit rates applied for credits and non-performing loan(NPL) ratios of participation banks, monthly interest rates applied for credits and NPL ratios of deposit banks for the time between January 2005 and September 2015 are used. The data were obtained from the official sites of the Banking Regulation and Supervision Agency of Turkey (BDDK), the Central Bank of Turkey and the participation 
banks. For determining the relationship between participation bank's profit rates and deposit bank's interest rates with NPL ratios; in E-views(statistical, forecasting, and modeling tools), correlation, unit root test, VAR, Granger causality, and impulse-response analyses are applied.

\section{Results}

Correlation analysis of the data with each other was examined by using the data of participation banks, profit rates, interest rates of deposit banks, NPL ratios of participation banks, and NPL ratios of deposit banks between the years 2005 and 2012. Between participation banks NPL ratios and deposit banks NPL ratios, there is 0.66 percent positive correlation. Between Participation banks profit rates and deposit banks interest rates, there is 0.91 percent positive correlation. Reason of this strong positive correlation between participation banks profit rates and deposit banks interest rates can be explained as; although there are differences in terms of operation, participation and deposit banks are determining the cost of loans according to similar factors. There is 0.27 percent positive correlation between participation bank's profit rates and participation bank's NPL ratios. There is 0.21 percent positive correlation between deposit bank's interest rates and deposit bank's NPL ratios. The direction of interaction between deposit bank's interest rates and deposit bank's NPL ratios is tried to be determined by using the Granger Causality test and there is a bi-directional and positive causality from NPL ratios to interest rates and interest rates to NPL ratios. The direction of interaction between parcipation bank's interest rates and participation bank's NPL ratios is tried to be determined by using the Granger Causality test and there is no causality between profit rates and NPL ratios.

\section{Conclusions}

In this article, relationship between profit rate, interest rate and NPL ratios at participation banks and deposit banks were examined. It is observed that participation bank's profit rates for credit are higher than deposit bank's interest rates for credit. In spite of higher financing costs, it can be said that it is because of religious concerns that customers prefer participation banks to Deposit banks. It is anticipated that participation bank's NPL ratios shal be higher than deposit bank's NPL ratios due to high profit rates for credit. According to results of analyses, it was found that NPL ratios are not direct result of profit/interest rates. In the light of analyses, it is determined that participation bank's higher profits rates for credit are not resulted to higher NPL ratio as it is foreseen.

Keywords : Participation Banks, Depozit Banks, Interest Rates, Profit Rates, NPL Ratios 